\title{
Towards Qualitative Computer Science Education: Engendering Effective Teaching Methods
}

\author{
Basirat A. Adenowo \\ Depart ment of Computer Science, AdeniranOgunsanya College of Education, Lagos, Nigeria \\ Email:b.adenowo@live.com \\ Stephen O. Adenle \\ Department of Science and Technology, University of Lagos, Lagos, Nigeria. \\ Email: drsadenle@yahoo.com \\ Adetokunbo A.A. Adenowo \\ Department of Electronic \& Computer Engineering, Lagos State University, Epe, Lagos - Nigeria. \\ Email: adetokyom@yahoo.com
}

\begin{abstract}
An investigation into the teaching method(s) that can effectively yield qualitative computer science education in Basic Schools becomes necessary due to the Nigerian government policy on education. The government's policy stipulates that every graduate of Basic Schools or UBE (Universal Basic education) should be computer literate. This policy intends to ensure her citizens are ICT (Information and Communication Technology) compliant. The foregoing thus necessitatesthe production of highly qualified manpower-grounded in computer knowledge-to implement the computer science education strand of the UBE curricu lum. Accordingly, this research investigates the opinion of computer teacher-trainees on the teaching methods used while on training. Some of the teachertrainees - that taught computer study while on teaching practice-were systematically sampled using "Purposive" sampling technique. The results show consensus in male and female teacher-trainees' views; both gender agreed that all the teaching methods used, while on training, will engender effective teaching of computer study. On the whole, the mean performance ratings of male teacher-trainees were found to be higher than that of females. However, this is not in accord with the target set by Universal Basic Education Commission which intends to eliminate gender disparity in the UBE programme. The results thussuggestthe need for further investigation using larger samp le.
\end{abstract}

Index Terms-ICT, UBE, Basic Education, Computer Science, Teaching Methods, Purposive Sampling.

\section{INTRODUCTION}

The introduction of compulsory computer science education into the UBE (Universal Basic Education) curriculum by the Nigeria government stems from the need to provide basic education for all and to enhance the computer literacy of her citizens. The global trend in educational system is to make primary and junior secondary school education, basic and compulsory [1]. In [2], Unagha affirms that the Universal Declaration of Human Rights which was asserted in 1948 states that everyone has the right to education. Since then there had been several efforts by every nation across the globe (Nigeria inclusive) to provide education as basic human right for her citizens. Thereafter, a World Conference on "Education for All" was held in Jomtien, Thailand, in order to formu late a global consensus and commitment towards providing basic education for all [2]. This actually gave birth to the Universal Basic Education (UBE) programme, and it was introduced into the Nigerian educational system in 1999 [3].

Presently in the Nigerian educational system, the UBE is the minimum level of education every leg itimate Nigerian is expected to attain as stipulated in the National Policy on Education. Also the minimum qualification allowed for teachers on UBE programme is the NCE (National Certificate in Education). The goal for awarding NCE is to produce teachers for the basic schools. It is as well stated in the National Policy on Education that the Nigerian government had to integrate ICT (Information and Communication Technology) education into her educational system due to the global trend and advances in technology [4]. Thus, the basic education includes computer science education in order to enhance national development.

In [5], Nwosuargues that teachers, being the major implementers of UBE programme must have the right mental attitude and be capable to impact the set goals in the learners at basic school level. As a result, there is need to engender quality computer-teacher preparation in tertiary institutions in order to produce qualified teachers who will effectively teach computer studies in our basic schools. The teacher-trainees should be equipped with appropriate teaching methods that enhance their teaching-performance at the Basic School 
level. Thus, this research seeks the opinion of computer science teacher-trainees about the teaching methods utilised while on training.

In order to address the foregoing, subsequent sections of this paper are structured as follows: a review of methods in-use for the training of computer teachers is presented in section II; section III provides overviewof the Universal Basic Education; and section IV describes the methodology employed in this work. The results of the empirical studies, findings and discussion of the findings are rendered in section V, while section VI provides the conclusion to the study. Recommendation and suggestions for future works are presented in sections VII and VIII respectively.

\section{COMPUTER TEACHERS’ TRAINING: METHODS IN-USE}

The NCCE (National Commission for Colleges of Education [6]) - the regulatory body in charge of the award of NCE, in its minimum standard curriculum, stipulates the various teaching methods that can be utilised in the training of computer science teachertrainees. This section presents an overview of each teaching method with the advantages and disadvantages.

\section{A. Lecture Method}

Lectures are very useful for introducing new subjects or topics, and for summarizing ideas. In [7], Olubiyi argues that lecture method is useful and easy in transferring knowledge to the students, and for handling moderate and large classes at once. It gives opportunity in reemphasizing main points which awakens learners' interest, thereby facilitating curious minds and critical thoughts. Lecture method encourages frequent questions, thus gives the trainees opportunities to express any doubts or misunderstandings they may be nursing.

However, lecture method inhibits students' participation and does not allow deep and active information processing that enhances information recall. According to Shakarian, see [8], the traditional lecture method may not be the most effective teaching strategy because it creates a predominantly passive learning experience where students, generally, are exposed to information, and are rarely given the opportunity to process it, and also prevents accurate notes taking.

\section{B. Discussion Method}

The discussion method is a group-learning method whereby the instructor and the students generate and share ideas, experiences, opinions, and information. According to Ajelabi as in [9], discussion method "is a participatory rather than autocratic approach to teaching and learning whereby the teacher and learners' contributions are essential," (p.68).Afe in [10] opines that discussion method makes the learner think critically and comparatively about the subject matter. Discussion promotes interaction with the rest of the group, and it instils social skills and character development in the students. However, not speculating limited scope or area to be covered can extend the teaching-learning period to an unreasonable length of time and make solution to the problem boring. The aforementioned can result in trainees losing focus on the central problem. This may result in unequal opportunities for the discussants.

\section{Practical Demonstration Method}

The practical demonstration method is a basic method of instruction for teaching skill-type subject matter. According to Olubiyi in [7], demonstration is used to teach how to perform certain skills. Availing trainees the opportunity to repeat the procedures and instantly correcting the trainees' mistakes make the method very effective and can help them learn the task more quickly. On the other hand, a good number of trainees may end up not understanding (especially in large classes) if demonstrator does not repeat difficult steps and pause to see trainees' reaction before moving to the next level. It can be stressful and quite expensive for the demonstrator.

\section{Tutorial Method}

Tutorial classes are rigorous intellectual exercise usually facilitated by having a student-leader or tutor presentation, followed by a discussion amongst the group, which later promote independent work. Before tutorials can be organised students must have been well exposed to the concept in classroom setting. According to [11], tutorials expose students further to already learnt concept through consultation, discussion and guidance from the instructor. Tutorials promote working within a team, nurturing critical thinking and independent learning in students. They, mostly, do not require elaborate structure or direction on the part of the tutor, because they are simply a thoughtful and constructive dialogue around issues raised in the readings or after the lecture. However, experience has shown that some students do not appreciate tutorial and prefer to study alone, because they perceive tutorials as mere repetitions of normal class sessions.

\section{E. Supervised Project Method}

Supervised Project method makes student go through independent study of real life situations as it relates to the subject matter learnt in the classroom. Ajelabi states that project carried out must be relevant to needs of the learners, the curriculum and the society at large [9]. A good advantage of project method, according to Afe [9], is that project method helps train the child to fit into his present society rather than preparing him for a future that is unknown. In [12], Fincher et al.also argues that projects should be focused on the growth of the student as a practitioner in order to demonstrate mastery of skills, while the supervisor nurtures it. However, due to single-student and single-supervis or relationship, there may be subjectivity in assessment. Another disadvantage occurs when supervised project is not focused on the growth of student-teacher as a practitioner; consequently, the teacher-trainee cannot apply acquired skills to real life situations. 


\section{F. Problem Solving/Inquiry Method}

Problem Solving/Inquiry Method is an innovative approach to learning, and it is a mental process that involves finding and shaping problems. According to SZ and Engin[13], problem solving/inquiry method is a Problem Based Learning method where students are actively involved in solving problems or providing answers to questions. Said et al. states in [14]that problem solving/inquiry method nurtures critical thinking and problem-solving skills which are central to a graduate's career. The former (i.e. [13]) also affirms that the tutor teaches skills within the problem context and exposes students to the learning experience acquired; these allow them to solve problems in their own terms and provide opportunity for active learning. However, Problem Solving/Inquiry Method requires higher-order cognitive processes, and development of very fundamental academic/problem solvingskills which many students may lack. It also consumes a lot of the teacher's time since he needs to make a lot of planning.

\section{G. Student's Guided Practice Method}

Student's Guided Practice Method is a means of facilitating the thought processes that are needed in applying scientific principles to problems. Afe in [10] states that student's guided practice method "is based on the assumption that the teacher will guide the learner's progress by means of commands and cues." Students' Guided Practice method offers opportunity for one-toone tutoring with constructive feedback, and improves learners' thinking abilities. On the other hand Student's Guided Practice Method can result in emotional imbalance for the learner because the teacher has to monitor learner's progress.

\section{H. Excursion Method}

An excursion can be defined as a trip by a group of people, usually made for leisure or educational purposes. According to Olubiyiin[7], excursion is an organized visit to special places in order to acquire direct learning experiences which classroom teaching cannot offer. Computer science teacher trainees are expected to make excursions to computer firms during their second year of study. Excursion trip can only be meaningful if the outcomes of the excursion are integrated into the teaching programmes, to improve teaching and learning processes. Due to the nature of excursion, teachers are forced to use new teaching methods which are not the regular practice during class sessions, thus new experiences are acquired. Hence, teachers become more confident in their post-excursion classroom practices. It also provides alternative learning strategy for students by improving their observation abilities since they are exposed to real life situation. So, excursions add variety that is beneficial to students and teachers, teaching and learning become more interesting and engaging. Some disadvantages of excursion method include time consumption and the associated high cost. It involves a lot of risk and may disrupt the school time table.

\section{Seminar Method}

Seminar is a form of academic instruction, carried out either in an academic institution or offered by a commercial or professional organization. It has the function of bringing together groups of people for recurring meetings, focusing-each time-on some particular topics, in which everyone present is requested to actively participate. Seminar is a student-centred teaching method which improves self-directed learning in students [15].

Computer science teacher-trainees carry out individual seminar presentation, on any topic in their area of study, in their final year session. According to Moreira and da Silva, seminar method avails studentstheopportunity to learn how to give and receive criticis $m$ in a constructive way [16]. This in turn increases the students' ability to interact and work in groups, which is an important skill for computer science professionals. Also there is opportunity for feedback [17]. However, seminar classes sometimes restrict the horizon of the learners or participants due to limited scope and guidelines.

\section{UNIVERSA L BASIC EDUCATION}

Universal Basic Education (UBE) was adopted into the Nigerian educational system in September 1999. It covers primary school and junior secondary school education.Nwosustates in [5] that UBE "is expected to provide qualitative, free and compulsory education to every Nigerian child from primary to junior secondary," (p.1).The basic education programme aims at ensuring that every Nigerian youth on graduation is sufficiently equipped with knowledge, skills, and experience required for initial entry into one occupation or another. Computer study is one of the subjects to be taught throughout the basic school. To this end, one cannot undermine the need to promote adequate teaching of this subject in the Universal Basic Education programme especially in this era of technology when computer is used in almost every facets of life.

According to the Nigerian 1999 constitution, as quoted in[5], one of the specific objectives of UBE is:ensuring the acquisition of the appropriate levels of literacy, numeracy, manipulative, communicative and life skills as well as the ethical, moral and civic values needed for laying a solid foundation for life - long learning and education.

This objective makes the teaching of computer study highly imperative in basic schools. Also, ensuring proper implementation of UBE goals calls for adequate training of the student-teachers. In that regard, the NCE has been prescribed the minimum teaching qualification and its holder are trained to teach in the Basic schools. The foregoing thus demands the exposure of studentteachers to diverse and effective teaching methods, especially, those applicable to the teaching of technology related courses such as computer science. This will help produce good and qualified teachers to 
implement computer study curriculum in Basic schools. By this way, effective classroom implementation of computerscience education curriculum can be ensured.

Nwosu states in [5] that "Teachers who must be engaged at this level must be those who have guts and the right mental attitude, capable to impact on the pupils the set objectives of the programme” (p.5).Therefore, one of the implementation strategies to adopt for the success of UBE programme is to train the studentteachers using appropriate teaching method(s). Obong in [18] argues that the Universal Basic Education Commission envisaged-during the 2006-2008 UBE Midterm Targets - $80 \%$ of Basic Education Teachers to have the Nigerian Certificate in Education (NCE), 10\% of Basic Education graduates to be computer literate, and to eliminate gender disparity in Basic Education.

\section{METHODOLOGY}

This study is a Survey research. It seeks the opinion of male and female computer science teacher-trainees on how the nine teaching methods, recommended to be used for the training of NCE graduates, will help facilitate effective teaching of computer study in Basic schools. The study's population comprises of all partthree (III) computer science students in two colleges of education in Lagos State: Aden ran Ogunsanya College of Education (AOCOED); and Federal College of Education Technical (FCET). Only part three students were considered because it is presumed that-at that level-their training would have involved diverse teaching methods. As at present, the part-III students being considered are in their Second Semester of the academic year and have undergone teaching practice in their respective placement schools.

Purposive sampling technique was used to compose the sample from each of the two institutions. This sampling method was used because only part three students who taught computer study during their teaching practice (TP) were considered the best target to provide data required. This actually restricted the number of cases that could be sampled. A total of 55 students were sampled for the study. There were 25 students from AOCOED and 30 from FCET. On gender distribution, there were 34 females and 21 males.
Five point Likert-scale questionnaire (tit led "Teachers' Effective Performance Scale” TEPS) was developed by the researchers and used for the data gathering. Face validity procedure was used in validating the instrument before embarking on data gathering. The researchers used split-half reliability method to obtain the coefficient of reliability. The split-half reliability method helps to determine if each half of the test (the odd and the even items) measures the same characteristics. The result obtained from the split-half, also known as coefficient of internal consistency (see figure 1 below), is 0.686 , approximately 0.7 . $\mathbf{r}_{\mathrm{sb}}=\mathbf{2} \mathbf{r}_{\mathrm{xy}} /\left(\mathbf{1}+\mathbf{r}_{\mathrm{xy}}\right)$ - where $\mathrm{r}_{\mathrm{sb}}=$ split- half
reliability coefficient and $r_{\mathrm{xy}}=$ correlation
between two halves of the scale

Figure 1: Sp lit-half (or Coefficient of Internal

Consistency) formula

\section{RESULTS, FINDINGS \& DISCUSSION}

\section{A. Presentation of Results}

Research Question 1: What is the difference between the perception of male and female computer science teacher-trainees in the contribution of lecture method towards effective teaching of computer studies in Basic Schools.

Outcome: Information presented in table I revealed that male and female students agreed that lecture method will promote high performance in Basic Schools (items $1 \& 2$ ), and they disagreed to item 3 which negates this fact (item 3: $x=3.048$ Males; $x=2.853$ Females).

Research Question 2: What is the difference between the perception of male and female computer science teacher-trainees in the contribution of discussion method towards effective teaching of computer studies in Basic Schools?

Outcome: As shown in table II both the male and female students agreed that discussion method will promote high performance in Basic schools (items 4 \& 5), and they disagreed to item 6 which negates the assertion (item 6: $\mathrm{x}=3.429$ Males; $\mathrm{x}=3.147$ Females). 
TABLE I: PERCEPTION OF MALE AND FEMALE TEACHER TRAINEES ON LECTURE METHOD

\begin{tabular}{|c|c|c|c|c|c|c|c|c|c|c|}
\hline \multirow[t]{2}{*}{ Items } & \multicolumn{5}{|c|}{ Males } & \multicolumn{5}{|c|}{ Females } \\
\hline & Min & Max & Mean & $\begin{array}{l}\text { Std. } \\
\text { Dev }\end{array}$ & Remark & Min & Max & Mean & $\begin{array}{l}\text { Std. } \\
\text { Dev }\end{array}$ & Remark \\
\hline $\begin{array}{l}\text { 1. As a result of my acquired } \\
\text { skills in lecture classes, I can } \\
\text { always pause to interact, using } \\
\text { question and answer method, } \\
\text { and also allow pupils to } \\
\text { expressany misunderstandings } \\
\text { in the course of the lesson. }\end{array}$ & 2 & 5 & 3.95 & .805 & Agree & 1 & 5 & 3.79 & 1.225 & Agree \\
\hline $\begin{array}{l}\text { 2. As a result of my acquired } \\
\text { skills in lecture classes, I can } \\
\text { reemphasize main points and } \\
\text { make good summary of } \\
\text { lessons thereby facilitating } \\
\text { curious minds and critical } \\
\text { thoughts in the pupils. }\end{array}$ & 3 & 5 & 4.29 & .561 & Agree & 1 & 5 & 3.97 & .904 & Agree \\
\hline $\begin{array}{l}\text { 3. I feel my experience in } \\
\text { lecture classes will not help } \\
\text { my teaching in basic school } \\
\text { because lessons taught with } \\
\text { lecture method are boring } \\
\text { when lecturers make repetition } \\
\text { of the concepts. }\end{array}$ & 1.00 & 5.00 & 3.048 & 1.1609 & Disagree & 1.00 & 5.00 & 2.853 & 1.2823 & Disagree \\
\hline
\end{tabular}

TABLE II: PERCEPTION OF MALE AND FEMALE TEA CHER TRAINEES ON DISCUSSION METHOD

\begin{tabular}{|c|c|c|c|c|c|c|c|c|c|c|}
\hline \multirow[t]{2}{*}{ Items } & \multicolumn{5}{|c|}{ Males } & \multicolumn{5}{|c|}{ Females } \\
\hline & Min & Max & Mean & $\begin{array}{l}\text { Std. } \\
\text { Dev }\end{array}$ & Remark & Min & Max & Mean & $\begin{array}{l}\text { Std. } \\
\text { Dev }\end{array}$ & Remark \\
\hline $\begin{array}{l}\text { 4. Based on my experience in } \\
\text { discussion classes, I can } \\
\text { stimulate thought and interest } \\
\text { of pupils in the topic of } \\
\text { discussion or subject matter. }\end{array}$ & 2 & 5 & 4.05 & .740 & Agree & 1 & 5 & 4.06 & .983 & Agree \\
\hline $\begin{array}{l}\text { 5. My experience in discussion } \\
\text { classes can enable me to } \\
\text { contribute towards the pupils' } \\
\text { character development and } \\
\text { train them in good interaction } \\
\text { and public relation. }\end{array}$ & 2 & 5 & 4.14 & .727 & Agree & 1 & 5 & 4.35 & .812 & Agree \\
\hline $\begin{array}{l}\text { 6. I feel Group discussions } \\
\text { bring rowdiness and there are } \\
\text { usually unequal opportunities } \\
\text { for learners. }\end{array}$ & 1.00 & 5.00 & 3.429 & $\begin{array}{c}1.325 \\
6\end{array}$ & Disagree & 1.00 & 5.00 & 3.147 & $\begin{array}{c}1.282 \\
3\end{array}$ & Disagree \\
\hline
\end{tabular}

Research Question 3: What is the difference between the perception of male and female computer science teacher-trainees in the contribution of practical demonstrator method towards effective teaching of computer studies in Basic Schools?

Outcome: The male and female students (table III) agreed that the practical demonstration method will contribute to high performance in Basic schools (items 7 $\& 8$ ), and they disagreed to item 9 that negates the statement (item 9: $\mathrm{x}=3.405$ Males; $\mathrm{x}=3.441$ Females).
Research Question 4: What is the difference between the perception of male and female computer science teacher-trainees in the contribution of tutorial method towards effective teaching of computer studies in Basic Schools.

Outcome: TableIV shows that male and female students agreed the tutorial teaching method will improve performance in Basic schools (items 10 \& 11), and they disagreed to item 12 that negates the fact (item 12: $\mathrm{x}=3.319$ Males; $\mathrm{x}=3.382$ Females). 
TABLE III: PERCEPTION OF MA LE A ND FEMALE TEACHER TRAINEES ON PRACTICAL DEMONSTRATION METHOD

\begin{tabular}{|c|c|c|c|c|c|c|c|c|c|c|}
\hline & \multicolumn{5}{|c|}{ Males } & \multicolumn{5}{|c|}{ Females } \\
\hline & Min & Max & Mean & $\begin{array}{l}\text { Std. } \\
\text { Dev }\end{array}$ & Remark & Min & Max & Mean & $\begin{array}{l}\text { Std. } \\
\text { Dev }\end{array}$ & Remark \\
\hline $\begin{array}{l}7 . \text { From my acquired } \\
\text { knowledge in practical } \\
\text { classes, I can teach practically } \\
\text { oriented topics to help the } \\
\text { average and slow learners } \\
\text { catch up with the level of the } \\
\text { class. }\end{array}$ & 1 & 5 & 3.76 & 1.221 & Agree & 1 & 5 & 3.88 & .946 & Agree \\
\hline $\begin{array}{l}\text { 8. From my acquired } \\
\text { knowledge in practical } \\
\text { classes, I can help the pupils } \\
\text { learn the task more quicklyby } \\
\text { availing trainees opportunity } \\
\text { to repeat the procedures and } \\
\text { instantly correcting their } \\
\text { mistakes. }\end{array}$ & 1 & 5 & 3.81 & 1.123 & Agree & 1 & 5 & 3.56 & 1.078 & Agree \\
\hline $\begin{array}{l}\text { 9. I fee practical classes may } \\
\text { not help my teaching in Basic } \\
\text { schools because of the much } \\
\text { stress involved in repeating } \\
\text { difficult steps and the need to } \\
\text { pause and confirm pupils' } \\
\text { understanding before moving } \\
\text { forward. }\end{array}$ & 1.00 & 5.00 & 3.405 & .94365 & Disagree & 1.00 & 5.00 & 3.441 & 1.1597 & Disagree \\
\hline
\end{tabular}

TABLE IV: PERCEPTION OF MA LE AND FEMA LE TEA CHER TRAINEES ON TUTORIAL METHOD

\begin{tabular}{|c|c|c|c|c|c|c|c|c|c|c|}
\hline \multirow[t]{2}{*}{ Items } & \multicolumn{5}{|c|}{ Males } & \multicolumn{5}{|c|}{ Females } \\
\hline & Min & Max & Mean & $\begin{array}{l}\text { Std. } \\
\text { Dev }\end{array}$ & Remark & Min & Max & Mean & $\begin{array}{l}\text { Std. } \\
\text { Dev }\end{array}$ & Remark \\
\hline $\begin{array}{l}\text { 10. Based on my experience } \\
\text { in tutorial classes, I can } \\
\text { guide my pupils to } \\
\text { independent learning and } \\
\text { nurture critical thin king in } \\
\text { them }\end{array}$ & 2 & 5 & 3.95 & .590 & Agree & 1 & 5 & 3.65 & 1.098 & Agree \\
\hline $\begin{array}{l}\text { 11. My experience in tutorial } \\
\text { classes can aid me to } \\
\text { inculcate in the pupils ability } \\
\text { to work within a team and } \\
\text { ability to commun icate ideas. }\end{array}$ & 2 & 5 & 3.90 & .625 & Agree & 1 & 5 & 3.79 & 978 & Agree \\
\hline $\begin{array}{l}\text { 12. I do not really find } \\
\text { tutorial classes useful in my } \\
\text { teacher training because they } \\
\text { are mere repetitions of } \\
\text { normal class sessions. }\end{array}$ & 1.00 & 5.00 & 3.319 & 1.3220 & Disagree & 1.00 & 5.00 & 3.382 & 1.3261 & Disagree \\
\hline
\end{tabular}

Research Question 5: What is the difference between the perception of male and female computer science teacher-trainees in the contribution of supervised project method towards effective teaching of computer studies in Basic Schools?

Outcome: According to results in table $\mathrm{V}$ male and female students also agreed that supervised project method will bring about high performance in Basic schools (items 13 \& 14), and they disagreed to item 15 which negates the statement (item 15: $\mathrm{x}=2.667$ Males; $\mathrm{x}=2.559$ Females).

Research Question 6: What is the difference between the perception of male and female computer science teacher-trainees in the contribution of problem solving/inquiry method towards effective teaching of computer studies in Basic Schools? 
Outcome: Information presented in table VI shows that male and female students agreed the problem solving/inquiry method will facilitate high performance in Basic Schools (items 16 \& 17), however they disagreed to item 18 which negates the fact(item 18: $\mathrm{x}=$ 3.167 Males; $\mathrm{x}=3.206$ Females).

TABLE V: PERCEPTION OF MALE AND FEMALE TEACHER TRA INEES ON SUPERVISED PROJECT METHOD

\begin{tabular}{|l|l|l|l|l|l|l|l|l|l|l|}
\hline \multicolumn{1}{|c|}{ Items } & Min & Max & Mean & $\begin{array}{l}\text { Std. } \\
\text { Dev }\end{array}$ & Remark & Min & Max & Mean & $\begin{array}{l}\text { Std. } \\
\text { Dev }\end{array}$ & Remark \\
\hline $\begin{array}{l}\text { 13. With my experience writing } \\
\text { final year supervised project, I } \\
\text { can make students learn and } \\
\text { master the subject matter as } \\
\text { applicable in real life. }\end{array}$ & 2 & 5 & 4.10 & .889 & Agree & 1 & 5 & 3.56 & 1.050 & Agree \\
\hline $\begin{array}{l}\text { 14. With my experience writing } \\
\text { final year project I can train the } \\
\text { pupils to demonstrate mastery } \\
\text { of skills in the topic learnt using } \\
\text { available instructional materials. }\end{array}$ & 1 & 5 & 4.19 & .873 & Agree & 1 & 5 & 3.91 & 1.055 & Agree \\
\hline $\begin{array}{l}\text { 15. my experience writing of } \\
\text { final year project will prevent } \\
\text { me from teaching pupils to } \\
\text { master the subject matter as } \\
\text { applicable in real life and the } \\
\text { use instructional materials } \\
\text { effectively in Basic schools. }\end{array}$ & & 5.00 & 2.667 & 1.3904 & Disagree & 1.00 & 5.00 & 2.559 & 1.2108 & Disagree \\
\hline
\end{tabular}

TABLE VI: PERCEPTION OF MALE AND FEMA LE TEA CHER TRAINEES ON PROBLEM SOLVING/INQUIRY METHOD

\begin{tabular}{|l|l|l|l|l|l|l|l|l|l|l|}
\hline Items & Min & Max & Mean & $\begin{array}{l}\text { Std. } \\
\text { Dev }\end{array}$ & Remark & Min & Max & Mean & $\begin{array}{l}\text { Std. } \\
\text { Dev }\end{array}$ & Remark \\
\hline $\begin{array}{l}\text { 16. Problem Solving/Inquiry } \\
\text { Method had equipped me such } \\
\text { that I can take learners through } \\
\text { learning experiences that allows } \\
\text { them solve problems in their } \\
\text { own terms and develop } \\
\text { (problem-solving skills). }\end{array}$ & 5 & 3.95 & .865 & Agree & 2 & 5 & 3.97 & .797 & Agree \\
\hline $\begin{array}{l}\text { 17. Problem Solving/Inquiry } \\
\text { Method had equipped me such } \\
\text { that I can nurture critical } \\
\text { thinking in the learners. }\end{array}$ & 5 & 4.05 & .669 & Agree & 3 & 5 & 4.29 & .524 & Agree \\
\hline $\begin{array}{l}\text { 18. I did not really acquire any } \\
\text { tangible skill learning with } \\
\text { Problem Solving/Inquiry } \\
\text { Method because it requires } \\
\text { higher-order cognitive } \\
\text { processes and development of } \\
\text { very fundamental } \\
\text { academic/problem solvingskills. }\end{array}$ & 5.00 & 3.167 & 1.2780 & Disagree & 1.00 & 5.00 & 3.206 & 1.2740 & Disagree \\
\hline
\end{tabular}

Research Question 7: What is the difference between the perception of male and female computer science teacher-trainees in the contribution of students' guided practice method towards effective teaching of computer studies in Basic Schools?

Outcome: TableVII below shows that male and female students agreed the students' guided practice method will facilitate high performance in Basic schools (items $19 \& 20$ ), and they disagreed to item 21 that negates the statement (item 21: $\mathrm{x}=3.143$ Males; $\mathrm{x}=$ 2.765 Females).

Research Question 8: What is the difference between the perception of male and female computer science teacher-trainees in the contribution of excursion method 
towards effective teaching of computer studies in Basic Schools?

Outcome: Also male and female students agreed that excursion method (table VIII) will contribute to high performance in Basic schools (items 22 \& 23), and they disagreed to item 24 which negates the statement (item 24: $\mathrm{x}=3.429$ Males; $\mathrm{x}=3.059$ Females).

Research Question 9: What is the difference between the perception of male and female computer science teacher-trainees in the contribution of seminar method towards effective teaching of computer studies in Basic Schools?

Outcome: TableIX shows that the two groups of students agreed the seminar method will promote high performance in Basic schools (items 25 \& 26), and they disagreed to item 27 which negates the fact (item 27: $x$ = 3.048 Males; $\mathrm{x}=2.206$ Females).

\section{TABLE VII: PERCEPTION OF MALE AND FEMA LE TEACHER TRAINEES ON STUDENTS’ GUIDED PRACTICE METHOD}

\begin{tabular}{|c|c|c|c|c|c|c|c|c|c|c|}
\hline \multirow[t]{2}{*}{ Items } & \multicolumn{5}{|c|}{ Males } & \multicolumn{5}{|c|}{ Females } \\
\hline & Min & Max & Mean & $\begin{array}{l}\text { Std. } \\
\text { Dev }\end{array}$ & Remark & Min & Max & Mean & $\begin{array}{l}\text { Std. } \\
\text { Dev }\end{array}$ & Remark \\
\hline $\begin{array}{l}\text { 19. Based on my experience in } \\
\text { Student's Guided Practice } \\
\text { exercises, I can effectively } \\
\text { offer one-to-one tutoring to } \\
\text { Basic school pupils. }\end{array}$ & 1 & 5 & 3.71 & 1.102 & Agree & 2 & 5 & 3.97 & .870 & Agree \\
\hline $\begin{array}{l}20 . \quad \text { My experience in } \\
\text { Student's Guided Practice } \\
\text { exercises can enable me } \\
\text { provide constructive feedback } \\
\text { to learners and improve } \\
\text { learners'thinking abilities. }\end{array}$ & & 5 & 3.81 & .814 & Agree & 1 & 5 & 3.71 & 1.060 & Agree \\
\hline $\begin{array}{l}\text { 21. Student's Guided Practice } \\
\text { Method did not really help my } \\
\text { learning while in training } \\
\text { because monitoring learner's } \\
\text { progress can result in } \\
\text { emotional imbalance for the } \\
\text { learner. }\end{array}$ & 1.00 & 5.00 & 3.143 & 1.2762 & Disagree & 1.00 & 5.00 & 2.765 & 1.2324 & Disagree \\
\hline
\end{tabular}

TABLE VIII: PERCEPTION OF MALE AND FEMALE TEA CHER TRAINEES ON EXCURSION METHOD

\begin{tabular}{|c|c|c|c|c|c|c|c|c|c|c|}
\hline \multirow[t]{2}{*}{ Items } & \multicolumn{5}{|c|}{ Males } & \multicolumn{5}{|c|}{ Females } \\
\hline & Min & Max & Mean & $\begin{array}{l}\text { Std. } \\
\text { Dev }\end{array}$ & Remark & Min & Max & Mean & $\begin{array}{l}\text { Std. } \\
\text { Dev }\end{array}$ & Remark \\
\hline $\begin{array}{l}\text { 22. My variety of experiences } \\
\text { during excursions can make } \\
\text { me very confident and teach } \\
\text { more effectively in Basic } \\
\text { school classrooms. }\end{array}$ & 1 & 5 & 4.10 & .889 & Agree & 2 & 5 & 3.53 & .961 & Agree \\
\hline $\begin{array}{l}\text { 23. Based on my experiences } \\
\text { during excursions, I can } \\
\text { improve classroom lessons and } \\
\text { make learning more interesting } \\
\text { using different teaching } \\
\text { strategies. }\end{array}$ & 1 & 5 & 4.00 & .837 & Agree & 2 & 5 & 3.76 & .855 & Agree \\
\hline $\begin{array}{l}\text { 24.I always feel to be } \\
\text { exempted from excursion } \\
\text { because it can be stressful and } \\
\text { mere waste of time and energy. }\end{array}$ & 1.00 & 5.00 & 3.429 & 1.4687 & Disagree & 1.00 & 5.00 & 3.059 & 1.2295 & Disagree \\
\hline
\end{tabular}


TABLE IX: PERCEPTION OF MALE AND FEMA LE TEACHER TRAINEES ON SEMINAR METHOD

\begin{tabular}{|l|c|c|c|c|c|c|c|c|c|c|}
\hline \multicolumn{1}{|c|}{ Items } & \multicolumn{3}{|c|}{ Males } & \multicolumn{3}{c|}{ Females } \\
\cline { 2 - 10 } & Min & Max & Mean & $\begin{array}{c}\text { Std. } \\
\text { Dev }\end{array}$ & Remark & Min & Max & Mean & $\begin{array}{c}\text { Std. } \\
\text { Dev }\end{array}$ & Remark \\
\hline $\begin{array}{l}\text { 25. With seminar experiences, } \\
\text { I can inculcate in my pupils } \\
\text { ability to give and receive } \\
\text { criticis m in a constructive } \\
\text { way. }\end{array}$ & 1 & 5 & 3.86 & 1.153 & Agree & 1 & 5 & 4.03 & .969 & Agree \\
\hline $\begin{array}{l}\text { 26. With seminar experiences, } \\
\text { I can inculcate the skills } \\
\text { needed to interact and work in } \\
\text { groups in Basic school pupils. }\end{array}$ & 2 & 5 & 3.86 & .964 & Agree & 1 & 5 & 3.79 & 1.175 & Agree \\
\hline $\begin{array}{l}\text { 27. Seminar classes sometimes } \\
\text { restrict the horizon of the } \\
\text { learners/participants. }\end{array}$ & 1.00 & 5.00 & 3.048 & 1.2032 & Disagree & 1.00 & 5.00 & 2.206 & 1.1489 & Disagree \\
\hline
\end{tabular}

Research Hypothesis 1: There is no significant difference between the mean ratings in effective performance of the male and female computer science teacher-trainees in the teaching of computer study.

Outcome: An independent sample t-test (table $\mathrm{X}$ and $\mathrm{XI})$ was conducted to compare mean ratings in Effective Performance scores of Male and Female students. Checking assumption for equality of variance, equality of variances was assumed (Sig. $>0.05$; Sig. $=0.074$ ). However, there was a significant difference in scores for males $(M=101.43, S D=8.29)$ and females $(M=96.21$, $\mathrm{SD}=9.65) ; \mathrm{t}(55)=2.05, \mathrm{p}=0.05$ (two-tailed).

From the result obtained there is a significant difference in Effective performance of males and females students, with the males having a higher mean score. So this Null hypothesis is rejected, and alternative hypothesis is upheld (There is significant difference between the mean ratings in effective performance of the male and female computer science teacher-trainees in the teaching of computer)

TABLE X: GROUP STATISTICS

\begin{tabular}{|l|l|r|r|r|r|}
\hline & Gender & $\mathrm{N}$ & Mean & Std. Deviation & Std. Error Mean \\
\hline \multirow{2}{*}{ TotalEffectivePerformanceScale } & Male & 21 & 101.4286 & 8.28596 & 1.80814 \\
\cline { 2 - 6 } & Female & 34 & 96.2059 & 9.65081 & 1.65510 \\
\hline
\end{tabular}

TABLE XI: INDEPENDENT SAMPLES T-TEST

\begin{tabular}{|c|c|c|c|c|c|c|}
\hline & & \multicolumn{2}{|c|}{$\begin{array}{l}\text { Levene's Test for } \\
\text { Equality of Variances }\end{array}$} & \multicolumn{3}{|c|}{ t-test for Equality of Means } \\
\hline & & $\mathrm{F}$ & Sig. & $\mathrm{t}$ & $\mathrm{Df}$ & Sig. (2-tailed) \\
\hline \multirow[t]{2}{*}{ TotalExpectedPerformanceScale } & $\begin{array}{|cc|}\text { Equal variances } \\
\text { assumed }\end{array}$ & .116 & .735 & 2.054 & 53 & .045 \\
\hline & $\begin{array}{l}\text { Equal variances not } \\
\text { assumed }\end{array}$ & & & 2.131 & 47.392 & .038 \\
\hline
\end{tabular}

\section{B. Summary of Findings}

1) Perception of Male and Female Computer Science Teacher Trainees on Effective Teaching of Computer Studies in Basic schools:

Results show that male and female students agreed that each of the nine teaching methods (lecture, discussion, practical, tutorial, supervised project, problem solving/inquiry, students' guided practice, excursion and seminar method) will contribute towards effective performance in the teaching of computer studies in Basic schools. Each group of students also disagreed that any of the teaching methods will not contribute towards effective performance.

\section{2) Mean Ratings of Male and Female Students:}

The mean rating of male students' teaching effectiveness is higher than that of female students. This is an indication that the quality of education male student-teachers have acquired in terms of how well 
they can disseminate knowledge, that is teach in Basic schools is higher than that of their female counterparts.

\section{Discussion of Results}

The result obtained regarding the males' effective performance rating being higher than that of females is not in accord with the targets set by Universal Basic Education Commission. As quoted above, the Universal Basic Education Commission intends to eliminate gender disparity in Basic Education. This gender disparity should be eliminated amongst UBE teachers, and among the pupils who will be the output of teachers' labour. The mean student- ratings of the teaching methods that are used in teacher training are primarily a function of the instructors who teach using these methods, rather than the course that is taught. Impliedly, how well a student-teacher teaches at the Basic Education level can be said to be a function of the quality of methods used while on the teacher-training education.

Therefore, lecturers should strategize in applying the teaching methods to ensure females are as well motivated as the males so that the two groups will have equal output from NCE education. This will facilitate equal input into the Basic school education by both sexes, thereby eradicating gender disparity as set by the UBE Commission. Moreover, lecturers from different institutions should endeavour to interact and exchange ideas on ways and means of disseminating knowledge through the various teaching methods towards improving teacher education. They can organize-on regular basis-seminars, workshops and conferences (which can be sponsored by the government)toenrich and improve Basic Schools teachers' training programme. The suggestions will go a long way to bridge the gaps that might exist in the products from different tertiary institutions meant to produce manpower for the Basic School's curriculum, especially, the computer science education aspect of the curriculum.

\section{CONCLUSION}

In conclusion, there is evident that the female students have not gained well enough, as the male students, from the teaching methods used. There is need for much improvement in handling the teaching methods in order to have better output. This will facilitate having quality male and female computer teachers with NCE award in Basic Schools. Invariably, the male and the female computer teachers will be able to produce more graduates of Basic Education that will be computer literate. Moreover, Basic School pupils will be able to learn equally from the female teachers, as much as they do with male teachers.

Furthermore, teachers that will be engaged at the UBE level will be those who have the right mental attitude and capability to impact on the pupils the set objectives of the UBE programme, especially, the computer science education strand of the programme. The Universal Basic Education Commission also envisaged $10 \%$ of Basic Education graduates to be computer literate within two years as quoted above. Thus, as qualified computer teachers are produced, the number of UBE graduates that are computer literate will continue to increase.

\section{RECOMMENDATIONS}

Based on the result obtained, the following recommendations are made towards engendering quality teacher preparation:

1) that lecturers in different colleges of education should interact and exchange ideas on ways and means of improving the use of teaching methods for teaching computer science.

2) that lecturers should endeavour to train well, using the various teaching methods as recommended in the NCCE curriculum, in order to meet up with the minimum standard recommended in training.

3) that lecturers should pay adequate attention to the training of female students as much as the males.

4) that government should encourage and motivate females students to show keen interest in learning.

5) that government should encourage andsponsor-regularly-training programmes that can enhance/update lecturers knowledge.

\section{SUGGESTIONS FOR FUTURE STUDIES}

As a result of the constraint in sample composition (that is, only part-three computer science students involved in teaching practice), it is therefore recommended that further investigation be conducted in this area using larger sample.

\section{REFERENCES}

[1] Global Action for Children http://www.globalactionforchildren.org/issues/basi c education/?gclid=CN Tq4HO2KACFRhp4wod d3AjCw [Accessed: 27/03/10: 10:30 am.]

[2] A. O. Unagha, "Implementing Universal Basic Education (UBE) through the Strategic Provision of School Library Services," Library Philosophy and Practice, 2008.

[3] V. W. Dike, "School library facilities required for successful implementation of the Universal Basic Education in Nigeria,” In: Proceedings of the 16th Annual Conference of the Nigerian School Library Association, Children's Centre Library, UNN, Nigeria, pp.2-7, 2000.

[4] National Policy on Education, 4th ed., Nigeria, 2004b.

[5] E. C. Nwosu, "The Universal Basic Education (UBE) Scheme in Nigeria: Objectives and Some Implementation Constraints," NER, 8(1), pp.1-8, 2003.

[6] National Commission for Colleges of Education 
Minimum Standards Curriculum for Nigeria Certificate in Education, 2004a.

[7] A. Olubiyi, Understanding Educational Technology,Evasan Limited, Lagos, 2000.

[8] D. C. Shakarian, "Beyond Lecture: Active Learning Strategies That Work," The Journal of Physical Education, Recreation \& Dance (JOPERD), Vol. 66, 1995.

[9] A. Ajelabi, Essentials of Educational Technology, 2nd ed., Raytel Communications Ltd., Lagos, 2005.

[10] O.J. Afe, Teacher Education in Nigeria: Trends, Issues and Challenges, Nigerian Educational Research Association (NERA), Nigeria, 1995.

[11] Teaching, Some Very Short Introductionshttp://www.csap.bham.ac.uk/resource s/guides/tutorials.htm, [Accessed: 04-03-2010, 10:16 am].

[12] S. Fincher, M. Petre and M. Clark, Computer Science Project Work: Principles and Prag matics, Springer-Verlag London Limited, Great Britain, 2001.

[13] S. N. A. SZ and L. S. Eng, “Integrating ProblemBased Learning (PBL) in Mathematics Method Course," Electronic Journal Of University Of Malaya, 2005.

[14] S. M. Said, "Implementation of the Problem-based Learning Approach in the Department of Electrical Engineering," European Journal of Engineering Education, 30(1), pp.129-136, 2005.

[15] B. S. Simelane et al., "Attitudes of Nursing Students Towards the Seminar Method of Teaching,” Curationis, 20 (1), pp.11-14, 1997.

[16] D. A. Moreira and E. Q. da Silva,“A Method to Increase Student Interaction Using Student Groups and Peer,"Educational and Information Technologies, 8 (1), pp.47-54, 2003.Top of Form.

[17] D. A. Rogers et al., "Computer-Assisted Learning versus a Lecture and Feedback Seminar for Teaching a Basic Surgical Technical Skill,” The American Journal of Surgery, 175(6), pp.508-510, 1998.

[18] J. O. Obongi, "The State of Basic Education in Nigeria: The Way Forward," In: Proceedings of 47th Annual Conference of Science Teachers Association of Nigeria (Stan), Calabar, Nigeria, 2006.

Basirat A. Adenowois a Senior Lecturer at the department of Computer Science, School of Science, AdeniranOgunsanya College of Education. Her teaching interests include system analysis and design, database management system, data structure, programming, etc.

She conducts research, majorly, in computer science education.

She received the B.Sc. degree in Computer Science in 1991 from University of Lagos, Lagos, Nigeria, and the PGDE degree in 2001 from Lagos State University, Ojo, Lagos, Nigeria, and the M.Sc. degree in Computing in 2009 from De Montfort University, Leicester, UK. She is a full member of Nigeria Computer Society (NCS), Computer Professionals of Nigeria $(\mathrm{CPN})$, Teachers Registration Council (TRC), Nigerian Association of Teachers' of Technology (NATT) and Science Teachers Association of Nigeria (STAN).She is also a member of Women in Colleges of Education (WICE).

Dr. Stephen O. Adenle is currently a Senior Lecturer at the department of Science and Technology Education, Faculty of Education, University of Lagos, Lagos, Nigeria. He teaches and conducts research in vocational and technology education, andresearch methodology Dr Adenle received BSc., MSc. and Ph.D. degrees in Industrial Technical Education in 1984, 1992 and 1997 respectively from the University of Nigeria, Nsukka (UNN). He belongs to a number of educational bodies such as Nigerian Association of Teachers' of Technology (NATT), Science Teachers' Association of Nigeria (STAN), Nigerian Vocational Association (NVA), to mention a few. He is also external examiner to Tai Solarin University of Education, Ijebu-Ode, Nigeria, Federal College of Education (Technical), Akoka, Lagos, Nigeria, and external assessor of academic papers of Yaba College of Technology, Yaba, Lagos, Nigeria.

Dr.Adetokunbo A.A. Adenowo is currently a lecturer and Ag. Head of Department, Electronic and Computer Engineering, Lagos State University, Lagos-Nigeria. His teaching focus includes software engineering, operating systems, database management system, algorithm analysis and data structures, and programming. His research interests areSoftware Engineering (with focus on Intelligent/Adaptive Technologies), Security Engineering (in contexts of Computer/Network Systems and Embedded Software) and Technology-Enhanced Learning (eLearning).

He received the BSc. and MSc. degrees in Computer Science in 1990 and 1995respectivelyfrom the University of Lagos, Nigeria, MBA degree in 2000 from Lagos State University, Nigeria, and Ph.D. degree in Software Engineering and eLearning in 2012 from De Montfort University, Leicester, UK..He is a member of a number of professional bodies, including IEEE, AIED (Artificial Intelligence in Education), NCS (Nigeria Computer Society) and NIM (Nigeria Institute of Management). 